\title{
Training of Students' Comprehensive Ability through Calligraphy Teaching in Colleges and Universities
}

\author{
Shoucun Li \\ Feixian College \\ Linyi University \\ Feixian, Linyi, Shandong, China
}

\begin{abstract}
The students' ability training through calligraphy teaching in universities is presented mainly as follows: Training of appreciation ability that stresses on communication between students and teachers and first gets a clear picture about what the students are thinking in study. Training of the observation ability is to make the students more initiative and comprehensive in outsight, training of imitation to make students able to understand things in a correct way, apprehensiveness training to make them comprehend by analogy, creative learning to shape them with creativity, and self-learning ability training to promote their investigative study.
\end{abstract}

Keywords-popular education; calligraphy teaching; ability training

\section{INTRODUCTION}

Training of students' ability through calligraphy teaching in universities mainly focuses on education in skills, theory and relevant knowledge. In this way, students can grasp and apply calligraphy knowledge in practice, which is a promotion for their study. This teaching method can not only improve the comprehensive ability of university students, but also train talents with general knowledge.

\section{TRAINING OF APPRECIATION ABILITY}

\section{A. Be Appreciative, Then Skillful}

During calligraphy teaching, teachers focus more on the training of skills, instead of their appreciation ability. So making students more appreciative is an issue that we are facing currently. Objectively, it is easy to teach skills in calligraphy courses. Teachers usually talk about the writing technique, structure, composition, model works, imitate writing and comment on works. While, what the students do is just listen to what their teachers say and accept it. Therefore, the communication between students and teachers should be increased, so that students can learn knowledge about skills and easily be trained to be more appreciative as well.

\section{B. Training of Students' Appreciation Ability Depends on Their Teachers}

Just as Marx put it, the most beautiful music has no meaning for the non-musical ear. Things go the same with calligraphy. For someone who can't appreciate it, the most excellent work has no meaning to him. Teachers can help training students' skills, but their ability of appreciation need the efforts of both students and teachers. At first, students should see as more works as possible. Then, they should be guided to appreciate those works. Teachers can give comments on students' works, lead them to exhibitions, help them with works by calligraphers and organize seminar about calligraphy to introduce appreciating methods.

\section{TRAINING OF OBSERVATION ABILITy}

\section{A. Make Students' Initiative in Observation and Broaden Their Vision}

Observation ability means the awareness of abstract form of calligraphy, which is the priority of learning calligraphy. Training of observation ability requires students' eyes much quicker than their hands. In general, those great calligraphers all do excellent in observation.

\section{B. Build Students' Ability of Awareness}

To find different point in works that others considered common can be the key for creative learning. Teachers can adopt different measures to train students' observation ability.For example, provide them with Inscription at Liquan in Jiucheng Palace in regular script with Ouyang Xun style and Qin Li Monument in regular script with Yan Zhenqing style. Let them figure out the differences in vertical, curved and hook stroke and right-falling stroke between these two works. Teachers can also present them with an unknown copybook for calligraphy and students are supposed to offer the basic feature of this work immediately.

\section{TRAINING OF IMITATION ABILITY}

\section{A. Training Students to Be More Accurate in Imitating}

The imitation in calligraphy is the ability to reproduce target works. The act of observation is training of eyes, while that of imitation is the process of training hands. Only by clearly observation can the copy work be like the real one. The ability of observation is reflected by imitation, so people's basic skills are judged by their imitation ability. Obviously, there is no object for students to copy from like painting. What they copy from are calligraphy works from ancient times. In order to increase the accuracy of their copy works, students should be trained to have good habits during imitating. Among 
these habits, reading, adjusting and rectifying are of great importance.

\section{B. Training the Students' Persistence in Imitating}

It means that they should be interested in this all the time and be able to resist the loneliness. For the long time imitating of a certain work, there must be sometime that they cannot concentrate on it. For example, when there are some difficult strokes that they can't draw even with a long time seeing, they may be depressed. In this case, teachers are supposed to tell them the importance of imitation, and tell that imitation is a thing that takes time and even great calligraphers often do, and then develop their habit of practicing all the time. Ask them to do homework until their habit is formed. What's more, students' interest and calligrapher should be combined and guided by teachers. That is to say, teachers should understand their students instead of taking their own course.

\section{Change and Efficiency during Imitating}

Numerous repetitions are needed for calligraphy imitation, only in this way can students' skills be improved. While, those repetition should be effective, which means that the students are supposed to know the difficulties and important points in the work before their imitating and check their imitating work after it. Change means that the application and combination of skills and features of two or more calligraphy works. This is a kind of imitation of high-level that those who are do well in calligraphy can achieve.

\section{AWARENESS TRAINING}

\section{A. Training Their Chanciness of Awareness}

Awareness means the ability to know and understand the inherent law and essence of calligraphy works. The ability of awareness is a consciousness of high degree which should be pursed all the time and it allows them to comprehend by analogy. If someone wants to have the ability of imitating, he or she must be able to see the features of the work, and then can he or she be equipped with the ability of awareness. So that students can change things they have learned to their own knowledge. Teachers should stimulate the students' interest in learning calligraphy and let them know the ability of awareness is get by chance after thinking repeatedly.

\section{B. Training Them to Be Able to Draw Inferences about Other Cases from One Instance}

The procedure of awareness generated from abstract, summarized and specified logical thinking. It is also a kind of awareness. Teachers should make efforts in the training of students' ability in this kind and lead them to summarize what they have learned. For example, guide them to find the power and rhythm in strokes and let them apply these findings in practice. In this way, the students can make their own calligraphy works full of changes in techniques of writing, such as rising stoke, pressing stroke and so on. Teachers can also change some parts of a certain work and let the students point out them. For example, stressing on the size of characters in left-right structure and making them apply in their own practice.

\section{Training Them to Be Extensive in the Source of Study}

Everything we learn is from the nature and society including calligraphy which is based on Chinese characters, so there is quantity of things that can help us get the ability of awareness. Everything is related with each other, those who can find these connections can know the essence and law among them. Calligraphy has something in common with music, dance, rhythm and ancient architecture. So some features of these things can also be applied in calligraphy. Therefore, in order to grasp these connections, students can combine calligraphy with knowledge of their own majors and write them down in the form of paper or calligraphy works.

\section{Training Them to Be CReAtive}

\section{A. Creativity in Calligraphy Is a Reflection of Comprehensive Ability}

During the teaching, we have found that students' ability in imitating is excellent, while they can't do well in their independent works. The reason might be their imitating skill is not mature and they haven't shown creativity in their calligraphy works.

The training of students' creative ability should be based on the consciousness of creative thinking by both students and teachers. Creativity means that students should be able to reunite the features of great works they have seen before. This action is a natural thing to a calligrapher with creative thinking. Memorize, image, disintegrate and reunite of things can be a kind of creative thinking in calligraphy presentation which means things someone see from others' works. The imagination derives from inspiration or intuition. However, inspiration is not a mysterious thing, and it is a result of appreciating and hardworking instead. Of course, there is someone born with inspiration what was called "Calligraphy Savvy" in ancient times. But it can be complimented by diligence afterward.

\section{B. Creative Learning Should Be Advocated in Calligraphy Teaching}

Students should also be able to do different kinds of practice and form the habit of multi-dimensional thinking. There are both divergent thinking (a way of thinking that is no constant way in thinking and result) and integration thinking (a way of thinking that suppose us to explore in a certain style and then reach our goal) in calligraphy learning. Though divergent thinking is adopt more, we still need to combine those two ways of thinking and make full use of image, replacement and recombination to find a practical way of being creative.

\section{TRAINING OF SELF-STUDY ABILITY}

\section{A. Make Self-study Plan}

Students need teachers and friends' help in calligraphy study, while what they need most is the ability to study by ourselves. So it is the priority for colleges and universities, especially comprehensive universities to stress on training students' self-study ability in teaching of calligraphy of 
primary, middle and high level. As the saying goes thatpreparedness ensures success and unpreparedness spells failure, it is necessary to set up a self-study plan which is inline with both the teaching aim and features of students' major. In this way, there is little randomness in learning and it is also a good way to encourage and supervise students to learn calligraphy.

\section{B. There Are Three Steps in Reading Copybooks}

The first step of reading needs the guidance from teachers. In this kind of teaching, teachers are supposed to adopt different methods and change the way of teaching from guidance to giving advice gradually. During reading, students are supposed to know the work's style and its characteristics of strokes and structure. And finally they are supposed to find the reason why characteristics and laws are presented like this. In the second step which is a little deeper than the first one, students are supposed to know the connection between its style and form, aesthetic preference of the calligrapher and the work's background. The last step is in a higher level than what we mentioned above. It contains the study on the spread of this work, the impact on later generations and what other calligraphers learned from this work.

\section{Revise by Students Themselves}

The reading and imitating of copy works above needs the revision from teachers, which is the primary stage of calligraphy learning. While hereafter, students should imitate whole work or part of the work and then compare their copy work with the original one and revise their own work. In this way, they can truly make progress. The ability for reading of original copybooks can be improved by the increase of their experiences and by going their teachers for help, while this is mainly rely on their own recognition. The points we have mentioned here are not all of them for calligraphy self-study. But what we dare to say is that self-study ability has closely relationship with their being great calligraphers. So it is a longterm task and responsibility for teachers of calligraphy to train students' self-study ability.

\section{REFERENCES}

[1] Outlook on Art Education in Comprehensive Universities-Summary on the Seminar of Educational Reform and Development in Art School of Shatou University [J].Jiangsu Pictorial.2003. (3).

[2] Zhang Jinghong. Thinking on the improvement of Studios for Tutors of Higher Educational Art Majors [J].Art Explorers.2003., (2).

[3] Bi Liyou. The Non-aesthetic Function of Calligraphy in Art Education [J].Art Education, sponsored by PRC Ministry of Culture.2005.5.

[4] Cai Yangyi. The Function of Calligraphy Teaching in Moral Education [J].Studies in Ideological Education. Research institute of ideological and political education in Colleges and Universities, sponsored by USTB (University of Science and Technology Beijing).2003.4. 